\title{
Veiledning i de videregående utdannelser
}

\author{
Gunnar Handal er professor emeritus i padagogik, Oslo Universitet, og Per Lauvås er professor $i$ \\ peedagogik ved Hogskolen $i$ Østfold.
}

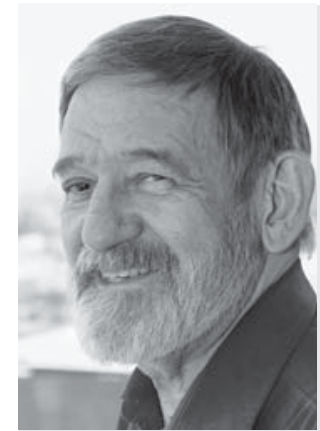

Gunnar Handal og Per Lauvås var lenge kolleger ved Universitetet i Oslo og har skrevet en rekke bøker hvorav noen også er utkommet i Danmark. Veiledning i ulike former og i ulike sammenhenger har vært et sterkt interessefelt for dem, særlig med tilknytning til de videregående utdannelser. Deres siste bok (Handal \& Lauvås (2006): Forskningsveilederen) er muligens deres siste bidrag på dette feltet. Handal er nå emeritus mens Lauvås arbeider ved Høgskolen i Østfold.

Forskningsvejledning, praksisvejledning, kollegavejledning, hvordan sikrer man kvalitet $i$ alle disse vejledningsformer $i$ uddannelsessystemet?, sporger forfatterne, og de argumenterer for at kvalitetsudviklinger af vejledning forudscetter italescettelse af tavs viden og lobende metakommunikation, både om vejledningens genstand og form. Og sådanne stadige forhandlinger og ekspliciteringer af gensidige forventninger og roller krever mod af både vejledere og vejledte.

"Veiledning er svaret. Hva var spørsmålet?« Noen ganger kan dette virke som et rimelig spørsmål. Veiledning - riktignok med mange forskjellige navn - synes å være ubetinget av det gode. Og da tenker vi ikke bare på tjenester som tilbys av coacher, mentorer eller personlige trenere med mer eller mindre solid bakgrunn for det de tilbyr. Også innenfor to solide og tradisjonelle former for veiledning med lang fartstid i høyere utdannelse, og som vi alle kommer i berøring med på dette utdannelsesnivået - forskningsveiledning og praksisveiledning $i$ tilknytning til profesjonelt arbeid - kan det være grunn til å stille spørsmålet om veiledning alltid er et ubetinget gode. Hvordan kan man sikre kvalitet i slik veiledning? Først noen ord til presisering av de to veiledningsformene vi sikter til: Med forskningsveiledning tenker vi på veiledning med studenter som skriver forskningspregete oppgaver som ledd i utdannelsen. Det gjelder selvsagt veiledning med $\mathrm{PhD}$-studenter og andre som arbeider med sin masteroppgave eller sitt 'speciale' som det vel fortsatt heter på dansk. Kanskje kan vi strekke denne veiledningen også til oppgaver av mindre omfang og med mindre forskningspreg - men ikke for langt.

Praksisveiledning i tilknytning til profesjonelt arbeid knytter seg kanskje særlig til profesjonsutdannelser der det inngår praksisperioder (leger, tannleger, lærere, arkitekter...). Ofte er det personer fra praksisfeltet som tar seg av denne veiledningen, men den er like fullt en del av det utdannelsesprogrammet studentene gjennomfører. Ellers er vel situasjonen slik at inkludering av praksisperioder i akademiske utdannelser kanskje ikke er så vanlig som en kunne forvente. Akademiet har en forkjærlighet for det teoretiske, abstrakte og generelle og overlater mer enn gjerne transformasjonen av slik kunnskap til studenten når hun eller han etter endt utdannelse trer ut $\mathrm{i}$ arbeidslivet.

I denne artikkelen skriver vi om begge disse veiledningssituasjonene - forskningsveiledning og praksisveiledning. Når det gjelder praksisveiledningen tillater vi oss dessuten å gjøre en vri på den og peke på de muligheter som ligger i gjensidig, kollegial veiledning mellom lærere i videregående utdannelse om deres praksis som lærere - en veiledning som i skremmende lav grad praktiseres i dag.

\section{Forskningsveiledning}

Forskningsveiledning foregår i stort omfang. I ikke alt for fjerne tider var veiledningen et gode som man kunne benytte seg av dersom man hadde tilgang til en veileder og dersom man fant at den veiledningen man fikk, var verd å bruke tiden på. Nå er veiledningen så å si blitt et obligatorisk innslag i det institusjonelle tilbudet til studentene på høyere nivå i utdannelsesystemet. Og kvaliteten er fortsatt av stor betydning. Dårlig veiledning er en av grunnene til dårlig gjennomføring (se f. eks. Degerblad \& Hägglund:2002). 


\section{Det verste: ikke-veiledning}

Lindén (1998) skjelner mellom noen hovedformer som veiledere benytter seg av i sin veiledning, nemlig personorientert, produktorientert og prosessorientert veiledning. Inndelingen har mye til felles med den inndelingen Tofteskov (1996) opererer med for prosjektveiledning, nemlig de to siste formene hos Lindén supplert med det han kaller laissez-faire- og kontrollveiledning. Tofteskov regner laissez-faire-veiledning som en aktuell form for prosjektveiledning. Det samme ser ikke ut til å gjelde i forskningsveiledningen. Mens et flertall av master- og $\mathrm{PhD}$-studenter synes å være rimelig godt fornøyd med den veiledningen de får, finnes det åpenbart en mindre gruppe som opplever det helt motsatte. I en svensk studie blant de doktorgradsstudentene som hadde avbrutt sine studier innenfor et fagområde ved en institusjon (Frischer \& Larsson, 2000) beskrives en form for kollektiv abdikasjon fra så vel veiledning som lederskap i forskeropplæringen. Det er ikke noen nådig karakteristikk de gir: "Focusing on the student-supervisor relationship, we encountered a laissez-faire situation of almost unbelievable dimensions." (Ibid.:153)

Men det ser også ut til å være mer subtile former for laissez-faire-veiledning som studenter finner høyst problematisk. Det kan se ut som følgende er det mest sentrale:Veiledere er "hideously overworked " (Rugg \& Petre, 2004), og veiledning er tidkrevende om man skal gjøre det som skal gjøres og gjøre det ordentlig. Anekdotiske beretninger om gode veiledere, inneholder ofte innslag om lesing lenge før morgenmat og tidlig på natten av ting studenten har skrevet. Et memento for veiledere må derfor ha flere ledd:

- Veiledning tar tid når man skal ta oppgaven på alvor. De veilederne som mener de kan lure studentene til å tro de har gjort ordentlig arbeid (for eksempel når de later som om de har lest et utkast til en tekst studenten har skrevet) gjennom å gi generell, substansfri ros ("Dette ser bra ut, bare gå videre!«), setter veiledningsrelasjonen i fare. Kanskje det er derfor studenter generelt er skeptiske til ros som mangler troverdighet fordi den ikke er tilstrekkelig underbygget og begrunnet?

- For studentene er ikke mangelfulle forberedelser og brutte avtaler kun et praktisk problem som fører til at eget arbeid blir forsinket. Det at veileder kan ta seg den frihet å gjøre dårlig arbeid og dessuten forsøke å skjule dette, er et signal om at relasjonen til studenten ikke er viktig. Og det er kanskje dette metabudskapet som har den sterkeste virkningen; Veileder ser ikke meg som så viktig at jeg blir tatt på alvor og behandlet med respekt, som fagperson og som medmenneske.

- Når det, til tross for de beste intensjoner, like fullt kan knipe med å få gjort det arbeidet som skal gjøres i veiledningen med studenten, er det kanskje bedre å involvere studenten mest mulig $\mathrm{i}$ den direkte plan- leggingen av dette samarbeidet. Det skulle ikke være vanskelig å få studenten til å innse at veileder har mer enn nok å gjøre og at man må finne den best mulige måten å organisere det praktiske samarbeidet. Da blir det nødvendig å planlegge på litt lang sikt, og studenten blir også nødt til å legge opp sitt eget arbeid med tanke på når veileder kan mobiliseres og når det er lite å hente fra veileder.

- Det kan også være nødvendig å tenke kreativt for å holde veilederes tidsbruk nede på et akseptabelt nivå. Innenfor økonomifaget i Sverige praktiserer f. eks. Rehn (2003) en veiledningsform som er lite tidkrevende for veileder (han kaller den 'quick and dirty') og trolig effektiv for hans studenter: studentene skriver kontinuerlig og veileder får tilgang til det som skrives men kommenterer lite og passer generelt på å bidra til at studenten fortsetter å produsere tekst. Den underliggende tanke er at tenkningen utvikles gjennom skriving, og at det kan utvikle seg til å bli noe bortimot et selvbedrag hvis man tenker å gjøre forskningen ferdig før man 'skriver det sammen til slutt'.

\section{Veiledningsrelasjonen}

Det er påfallende at litteraturen om forskningsveiledning så ofte fokuserer selve veiledningsrelasjonen. Hvorfor ser dette ut til å være så spesielt viktig? Her er det en tilsynelatende ukomplisert samarbeidsrelasjon det er snakk om, velorganisert og godt institusjonelt foreskrevet og forankret blant personer med toppkompetanse og alle tenkelige forutsetninger for å få til et slikt samarbeid. Så hvorfor den nærmest maniske opptatthet av selve veiledningsrelasjonen?

Svaret ligger i dagen: Relasjonen mellom veileder og student er en ubestemt relasjon der begge parter både har klare, bevisste forventninger til den og mer bakenforliggende modeller som verken veileder eller student har et helt bevisst forhold. Grant (2005) har på en innsiktsfull måte vist hvordan mer eller mindre rasjonelle faktorer spiller inn og bidrar til at veiledningsrelasjonen ofte kan bli en arena for skjult kamp og konflikt knyttet til slike forhold som makt, autonomi, selvstendighet, avhengighet og underkastelse. Det er en asymmetrisk relasjon idet det er veileder som har den dominante posisjonen, ikke på alle relevante områder, men på de mest sentrale og relevante. Og selv om studenten ikke akkurat innser at så er tilfelle, er selve konstellasjonen med en dominant samspiller eller motpart av natur slik at tidligere erfaringer med foreldre, foresatte, lærere og andre autoritetsfigurer lett mobiliseres.

Som veiledere har vi mer eller mindre klare forestillinger om hva veilederrollen innebærer. Det kan se ut som om den vanligste forestillingen i praksis fortsatt er veilederen som mester med studenten som lærling, i hvert fall om man skal bedømme dette ut fra internasjonal litteratur (se for eksempel Dysthe 2002, Han- 
dal \& Lauvås 2006). Og selv i samtidig litteratur er tanken om studenten som mesterens disippel, levende. Også blant studenter finnes det dem som synes at det eneste riktige er at veilederen er guru, den som bestemmer, gir oppdrag og kontrollerer om resultatet er riktig.Vi finner trolig den slags forventninger aller sterkest uttrykt blant studenter som kommer fra andre og sterkere stratifiserte kulturer. Man kan få sammenfall mellom forventningene hos de to i enkelte veiledningspar. Men det kan også være ganske store forskjeller i forventninger til rollene som veileder og student og til relasjonen mellom dem. Og kanskje er det ambivalensen hos begge parter - det samtidige ønsket om autonomi og selvstendighet på den ene siden og underkastelse og ansvarsfrihet på den andre siden - som gjør denne relasjonsavklaringen så viktig og så vanskelig.

Bartlett \& Mercer (2000) er ikke alene om å sette spørsmålstegn ved den gjengse forestillingsverdenen om veiledning som grunnleggende patriarkalsk, med innebygde konflikter, isolasjon og "fraught discipleship" dypt utilfredsstillende, i hvert fall for sin egen veiledning. De synes det er helt nødvendig å finne fram til mer velegnete tankemodeller. Dysthe (2002) foreslår en 'partnerskapsmodell' som en alternativ lest å sy veiledningsrelasjonen over. Dette stemmer godt overens med utviklingen $i$ andre land. I Australia fant for eksempel Johnson (1997) at den vanligste forestillingen i hennes utvalg var veilederen som guide. Idealbildet der var et samarbeid mellom en selvstendig forskerstudent som er sterkt opptatt av sitt akademiske og intellektuelle prosjekt og en veileder som fungerer som guide på veien.Veien er ikke bestemt på forhånd men avklares og bestemmes gjennom forløpet i en mest mulig likeverdig dialog. Riktignok kan det aldri bli en fullstendig likeverdig dialog. Det er et asymmetrisk par og skal være det.

I litteraturen om forskningsveiledning er det påfallende mange metaforer som skal søke å fange relasjonen i veiledning. Det dreier seg om typiske vertikale relasjoner (direktør - underordnet, prosjektleder - prosjektansatt), om kompetanseforskjeller (guru - disippel, ekspert - novise) eller om mer likeverdige relasjoner (venn - venn eller kollega - kollega). Mange har gitt uttrykk for at relasjonen mellom den som veileder og den som blir veiledet er vanskelig å definere. Derfor ser det ut til at et generelt råd er å la relasjonen bli et samtaletema, fra først til sist: hvilket samarbeid skal man bedrive, hvilke forventinger har partene og hvilke rettigheter og plikter skal defineres.

\section{Utviklingen av veiledningen gjennom forløpet}

Også veilederelasjonen må - og skal - utvikles over et så langt tidsrom som et $\mathrm{PhD}$-forløp eller også på mastergradsnivå. Ett aspekt får illustrere poenget her.Ved starten av et veiledningssamarbeid er det veileder som definitivt kan mest om det studenten skal arbeide med; det er denne differansen som er selve grunnlaget for at veileder blir veileder for den aktuelle studenten. Fra dette utgangspunktet vil veiledere forholde seg temmelig ulikt til kompetanseforskjellene mellom de to. Mens noen veiledere kan komme til å påta seg mye arbeid for hele tiden å vise seg mer kompetent enn studenten på det aktuelle forskningsfeltet, vil andre ikke ha en slik ambisjon. På ett eller annet tidspunkt skjer det en endring. Studenten overgår veilederen i kunnskap om det bestemte feltet som oppgaven handler om. Selvsagt er dette et teoretisk punkt som aldri inntrer på et bestemt klokkeslett. Men det er et viktig og interessant punkt.

For veiledere som selv synes at de hele tiden må være 'one up' for i det hele tatt å kunne fungere som veiledere, kan studenten nå bli betraktet som en rival. Maktkampen kan bli vond, særlig for studenten.

For veiledere som ikke ser det som avgjørende å opprettholde ekspertrollen i forholdet til studenten, kan dette punktet nærmest være et mål som så å si må feires når det er nådd. Og begge parter har formodentlig ambivalente følelser knyttet til dette. For studenten er det både en lykke å ha kommet så langt at man er helt $\mathrm{i}$ fronten på det aktuelle området, samtidig som det kan være en smule angstprovoserende når man nå selvstendig og offentlig må forsvare sitt arbeid og ikke lenger kan søke ly bak andre (for eksempel veileder). For veileder er det dypt tilfredsstillende å kunne konstatere at studenten har utviklet seg godt og nå er kommet helt $\mathrm{i}$ front. Dette kan være en av de store gledene ved å være veileder (Bergenheim 2001), men samtidig kan det for alle være vanskelig å innstille seg på at det nå er studenten som for eksempel skal uttale seg i media og at en selv skal tre i bakgrunnen. Relasjonen mellom de to må i hvert fall 'reforhandles'.

\section{Veiledningsformer $\mathrm{i}$ ulike faser}

En veiledningsform som sjelden er eksplisitt omtalt i litteraturen men som finnes i rikt monn blant veilederne, er 'ad hoc-veiledning'. Med dette tenkes det på kortfattet, løpende veiledning i tilknytning til det daglige arbeidet. Når studenten i et laboratoriefag står overfor et problem man selv ikke finner løsning på, kan veileder mobiliseres. Studenten bringer typisk med seg et problem (en datautskrift, resultater det ikke er lett å tolke, et metodisk problem osv) som adresseres i veiledningen. I noen miljøer kan det virke som om dette er den dominerende formen. Så lenge studenten ikke mobiliserer veileder $i$ forbindelse med konkrete problemer, regnes det med at arbeidet går godt, og det er kun kontroll og oppfølging av progresjon som er nødvendig. Denne formen er det knapt noen grunn til å teoretisere mye over; det største problemet med den er kanskje å regulere omfanget. Noen studenter kan misbruke lett tilgjengelige veiledere og tenke for lite selv, mens andre holder på for lenge på egen hånd med problemer som veileder burde vært koplet inn på tidligere. 
Det mest vanlige skillet ellers, ser imidlertid ut til å gå mellom 'prosessveiledning' og 'produktveiledning'. Prosessveilederen (om en slik veileder finnes i rendyrket form i det virkelige liv) er en som setter studentens arbeidsprosess $\mathrm{i}$ fokus og som har mindre fokus på kvaliteten i det som produseres. Veilederen er primært opptatt av studentens arbeids- (og skriveprosess) og legger vekt på å bistå studenten til å arbeide mest mulig målrettet og effektivt. Produktveilederen (igjen med forbehold om rendyrket forekomst) leser tekster, vurderer dem i forhold til kravene til et ferdig produkt og gir råd om hvordan teksten skal kunne forbedres. Mens prosessveilederen er mer opptatt av å bidra til at studenten organiserer sitt arbeid slik at det blir en best mulig skriveprosess, bryr produktveilederen seg mindre om skriveprosessen og mest av alt om kvaliteten på de tekstene som produseres.

Det er ikke holdbart å framstille disse to veiledningsarketypene nærmest som en funksjon av ulike personlighetstrekk hos veiledere.Vi opplever fra tid til annen at diskusjonen kolleger imellom baserer seg på et slikt utgangspunkt. En bedre måte er kanskje å tenke at studentene trenger ulik veiledning $i$ ulike faser av sitt arbeid. Det kan for eksempel være fornuftig å forsøke å organisere skriving av utkast (til deler av en artikkel eller en monografi) som mest mulig intensive skriveperioder. Da vil det både være et tema i prosessveiledningen å stimulere studenten til å organisere arbeidet på en slik måte, å bistå studenten i planleggingen av slike perioder og gi råd om hvordan man virkelig kommer i gang med å skrive utkast. Kanskje bør studenten starte med tankeskriving og ikke på utkast til selve avhandlingsteksten (se for eksempel Brown 1994, Dysthe 2000, Stray Jørgensen \& Rienecker 2006)? I selve skriveperioden er det neppe fruktbart å drive produktveiledning. Kanskje det til og med er direkte uheldig om veileder faller ned i tilvante spor og responderer som produktveileder i en slik skrivefase. Kanskje det aller viktigste for veiledere i en slik fase er å sørge for at studenten forblir i skrivemodus og ikke trekkes ut av den med forventninger om at et utkast som veileder har lest, skal revideres for man går videre i skrivingen av utkast? Kanskje det til og med er så et gjengs problem med skrivevegring blant avhandlingsstudenter (se for eksempel Delamont et al 2004, Larsson 2004, Rugg \& Petre 2004, Stenström 2003) at man bør være ganske omhyggelig med prosessveiledningen?

Det er imidlertid viktig at veileder og student har en felles oppfatning om hvilken form for veiledning det er snakk om til enhver tid, det vil si at veksling mellom og vektleggingen av - de to hovedformene er et sentralt samtale- og forhandlingstema i veiledningen. Ad hocveiledningen trenger man ikke avtale på samme måte. Her er det mer snakk om å regulere mengden av slik veiledning, både for å unngå at studenten har for høy og for lav sperre for å mobilisere veileder.
Det er kanskje særlig i produktveiledningen at vi må returnere til det vi startet med i denne artikkelen. Det å gi feedback på utkast, er slett ikke så enkelt som man kunne tro. I tillegg til vårt innledningspoeng om grundighet når man ikke har tid til å være så grundig som man gjerne vil være, kan det være grunn til å tenke nøye igjennom hva som egentlig er konstruktiv og effektiv feedback, og hvilke feil man kan komme til å begå. Her finnes det etter hvert mye å støtte seg til i litteraturen (se for eksempel Brinko 1993, Lauvås \& Handal 2005, Stray Jørgensen \& Rienecker 2006). Kanskje et så trivielt poeng som følgende kan sette egen tankevirksomhet $\mathrm{i}$ bevegelse: I stedet for å gi direkte, muntlig feedback - over bordet - til et utkast ved å gjennomgå de punktene som veileder synes det er viktig å ta opp, kan studenten făr veileders skriftlige kommentarer til teksten litt tid på forhånd $\mathrm{og}$, på det grunnlaget selv bestemme hva veiledningstiden bør brukes til? Så kan kanskje studenten få forberedt seg til å diskutere det som det er viktig - for studenten! - å få diskutert grundig i veiledningstiden.

\section{Samtale om de vanskelige periodene?}

På ett punkt ser det ut til at veiledere deler seg i to grupperinger, de som gjør det og de som slett ikke gjør det. Omfatter veiledningen også samtaler om opp- og nedturer i studentens arbeid, særlig det siste? Veiledere kjenner seg som regel igjen i beskrivelser av et avhandlingsforløp som svinger sterkt fra noen berusende og euforiske øyeblikk av suksess og tunge perioder der troen på at man skal klare å gjennomføre løpet, settes på harde prøver. De klassiske kjennetegnene (det Brown \& Atkins (1988) kaller 'warning indicators') kjenner vi til, kanskje særlig når studenten glir unna, både fra arbeidet og fra veiledningen, når vi får høre mer om hva som skal gjøres enn at vi ser resultater av det som er gjort og så videre. Men hvordan vi velger å forholde oss til disse nedturene, varierer kanskje mer blant veiledere enn de fleste andre aspektene ved veiledning. Lykkes vi på dette feltet, kan vi trolig bidra sterkt til at studentene klarer å gjennomføre sitt avhandlingsarbeid og komme ut med et resultat som de er stolte over. Ignorerer vi problemstillingen eller intervenerer på uheldige måter, vil vi trolig kunne bidra til den dårlige gjennomføringsstatistikken innenfor en del disipliner og fagområder. Lykkes vi, gir veiledningsoppgaven en dyp tilfredsstillelse av å se yngre kollegaer vokse og utvikle seg til å bli riktig gode forskere - og veiledere - som kan bringe vårt eget arbeid videre.

\section{Praksisveiledning}

Veiledning av studenter som er i praksis som del av sin utdanning får lett preg av supervisjon, dvs overvåking og kontroll av at de ikke gjør noe (iallfall ikke for mye) galt. Dessuten gjelder det å gi dem klar in- 
struksjon om hvordan de skal arbeide, demonstrere god praksisutøvelse for dem og korrigere dem når de selv prøver. Denne modellen for veiledning sitter dypt i ryggmargen på mange av oss og stemmer - overflatisk sett - med mesterlæren der svennen antas å lære nettopp gjennom en slik form for opplæring. Nielsen og Kvale har riktignok i sin bok »Mesterlære» (1999) nyansert denne hverdagsforståelsen og knyttet den til sosiokulturell læringsteori. Men likevel er vanlig praksisveiledning fortsatt mye preget av en enkel forståelse av hvordan man lærer i praksissituasjoner. Bistand til slik læring skjer særlig gjennom tilbud om modelllæring ved observasjon og etterligning av profesjonelle yrkesutøvere og mer eller mindre systematisk tilbakemelding på studentenes egne forsøk. Planlagte og jevnlige veiledningssamtaler knyttet til forsøk på yrkesutøvelse er derimot ikke et like vanlig trekk ved denne formen for praksisveiledning.

Wichmann-Hansen (2004) har vist at selv tilgang til observasjon av praksis er et begrenset gode i dansk medisinsk utdannelse. Studenter som utplasseres på sykehusavdelinger under studiet har til dels store problemer med å fă selv en »legitim perifer posisjon" (som det heter i Mesterlæren) i den praksis som foregår på avdelingene og at de kjemper om å bli sett, akseptert og inkludert i praksisfellesskapet slik at god læring kan oppstå. En annen betingelse for god læring i slike sammenhenger er at den preges av gjennomsiktighet $\mathrm{i}$ betydningen av at det som foregår blir gjort forståelig og meningsfullt for studentene som deltar (Lave \& Wenger 1991). Å observere - enn si modellere - en praksis en ikke begriper, gir liten mening, men dette er heller ikke en uvanlig situasjon for studenter som deltar i slike former for praksis (Ludvigsen 1998).

Det skal likevel erkjennes at en godt tilrettelagt praksis preget av mesterlære som fyller sine kvalitative kjennetegn, kan være lærerik for studenter.Vi vil imidlertid hevde at læringsverdien kan økes betraktelig dersom den kombineres med vel gjennomførte veiledningssamtaler - som vi skriver om nedenfor.

En reflekterende veiledning som vi har arbeidet mye med og skrevet om i bøker som også er tilgjengelig på dansk (Handal \& Lauvås 2002, Lauvås \& Handal 1997, Lauvås, Lycke \& Handal 1996, Lauvås \& Rump 2001), søker å kombinere handling (yrkespraksis) med refleksjon over slik handling med sikte på å utvikle det som ligger 'bak' handlingene, og som vi kaller 'praksisteorien' (eller 'den praktiske fagteori' som vi også har kalt den). En yrkesutøvers praksisteori er det sammenvevde construct av kunnskaper, erfaringer og verdier som er relevante som vedkommendes egen bakgrunn for valg av måter å utøve sin praksis på, innen de rammer som er gitt. Veiledning drives med sikte på å bevisstgjøre studenten (eller den profesjonelle yrkesutøveren for den saks skyld) om aspekter ved praksisteorien, støtte og utfordre den, bidra til å utvide og konsolidere den - og hele tiden se den i forhold til konkrete eksempler på yrkespraksis som den veiledete står overfor.

En slik veiledning tar utgangspunkt i konkrete, avgrensete eksempler på yrkespraksis som studenten skal gjennomføre. Ideelt foregår det forveiledning basert på et kort skriftlig notat om hvordan studenten har tenkt seg denne praksisen (et veiledningsgrunnlag). I veiledningssamtalen er det så veilederens oppgave å bistå studenten i å bli klar over hvilke kunnskaper, erfaringer og verdier studenten tenker å realisere gjennom den planlagte praksisen, støtte og/eller utfordre disse, bidra med innspill av annen kunnskap, erfaring eller verdiperspektiver og drøfte dette med studenten. Hensikten er altså ikke primært å få til en endret praksis (selv om også det kan bli en konsekvens av veiledningen) men å bidra til bevisstgjøring og utvikling av studentens praksisteori. Deretter gjennomfores praksisen - slik den først var tenkt eller $\mathrm{i}$ justert form som et resultat av veiledningen - fortrinnsvis med veilederen som observator (om det er mulig).Veiledningssekvensen avsluttes med en etterveiledningssamtale der en drøfter hvordan det som har skjedd har bidratt til å styrke, justere eller utvikle praksisteorien.

Tankegangen med en slik reflekterende veiledning er nettopp å komme i inngrep med den forståelsen av yrkespraksisen - i dens mange former - som studenten mer eller mindre bevisst er bærer av, og arbeide med utvikling av den. Det er nemlig praksisteorien som i fortsettelsen vil være den sterkest styrende kraft for studenten i utøvelsen av yrkespraksis, innenfor de rammer en til enhver tid er underlagt.

Dette er en veiledningsforståelse som umiddelbart bør kunne appellere til veiledere innen akademisk pregete utdannelser, nettopp fordi den er opptatt av den forståelse (i vid betydning) som ligger til grunn for våre handlinger. Det er jo nettopp kunnskaper, erfaringer og verdier vi er opptatt av i akademisk utdannelse og å bidra til at studenter kobler disse til profesjonell praksis, bør være en utfordring det er vanskelig å motstå.

Gjennomføring av en reflekterende veiledning kan imidlertid være krevende både for veileder og student, nettopp fordi den forutsetter at en del bilder vi bærer med oss om veiledning, må endres. Veilederen er ikke her primært en praksisutøvende modell, instruktør og kontrollør. Han/hun er en reflekterende praktiker som medvirker som analytiker og tolk i forhold til de praksissituasjoner student og veileder får tilgang til (gjennom observasjon og egen utøvelse). Det blir viktig for studenten å lete i sin bevissthet etter det en bygger på når en handler og være innstilt på å vurdere korrektiver til og utvidelser av dette grunnlaget som en blir overbevist om at en vil ta til seg. Veilederen blir en ressurs og en 'sparringpartner' i refleksjon over praksis, ikke en fasit for hvordan det egentlig skal være. Og - som sagt ovenfor - dette minner vel ganske mye om det som ideelt sett er en vitenskapelig holdning både til teori og praksis og dermed i tråd med akademiske idealer. Med 
andre ord burde dette være en veiledning en gjerne kunne drive innen videregående utdannelse.

\section{Kollegaveiledning blant universitetslærere}

Vi lovet innledningsvis at vi skulle gjøre en liten vri på praksisveiledningen og sette fokus på veiledning av universitetslærere i forhold til deres egen praksis som levere. Også personer som arbeider innen et yrke - som for eksempel lærere i videregående utdannelse - kan nemlig ha behov for veiledning. Dette kan være en spesiell utfordringen når det dreier seg om yrkesutøvere som $i$ mange tilfeller ikke har noen formell utdannelse for en sentral del av yrkesutøvelsen - nemlig undervisningen Riktignok har de masser av kompetanse når de gjelder innholdet $\mathrm{i}$ undervisningen, men det er kvalifiseringen for undervisningsprosessen vi tenker på her.

Både i norsk og dansk universitetspedagogisk kursvirksomhet foregår det veiledning i tilknytning til undervisningspraksis i mer eller mindre organisert form. Men siden kursene er kortvarige, blir slik veiledning sjelden mer enn en illustrasjon av hvordan den kan praktiseres. Erfaring fra våre kurs $\mathrm{i}$ Norge, er imidlertid at dette er noe av det deltakerne vurderer som mest positivt og lærerikt. Det vi vil fokusere på her, er imidlertid den muligheten som ligger i gjensidig kollegial veiledning om undervisning.

Vi tenker da på samme måte som i praksisveiledningen av studenter ovenfor: Den som skal fă veiledning skriver et veiledningsgrunnlag, det gjennomføres førveiledning ut fra dette med en kollega som veileder, undervisningen gjennomføres (fortrinnsvis med veilederen som observatør) og til slutt er det etterveiledning. Hele tiden er det praksisteorien til den som veiledes som er i fokus: Hvorfor gjør du slik, og finnes det annen kunnskap, erfaring og verdier som det kan være aktuelt å bake inn i praksisteorien? Får dette noen konsekvenser for det du vil gjøre i slik undervisning? Så vendes rollene; den som ble veiledet blir veileder for den som var veileder og det hele gjentar seg. Vi har vennet oss til å bruke veiledningsgrupper med tre personer, der en person til enhver tid er observatør til det som foregår og der også denne rollen går på omgang. Det gir mulighet for observatøren til å ha fokus på hvordan veiledningen foregår, slik at deltakerne kan utvikle sine kvalifikasjoner også for kollegial veiledning, ikke bare for undervisning. Dessuten gir en gruppe på tre en litt større variasjon både $\mathrm{i}$ innhold og former for undervisning som gruppen făr tilgang til enn med bare to deltakere.

Umiddelbart kan dette virke skummelt å delta i. Det er noe merkelig som inntreffer i undervisning når en kollega kommer inn som tilhører. Mens vi kan føle oss fortrolig med å undervise for 100 studenter, blir vi noe mer urolig når én kollega gjør sin entré. Men vår - og deltakeres - erfaring tilsier at dette går over når veiledningen kommer $\mathrm{i}$ gang.
Et forsøk med slik kollegial veiledning mellom universitetslærere foregår ved Århus Universitet. En gruppe på 35 lærere fra flere fakulteter har gjennomført et ettårig prosjekt der de $\mathrm{i}$ grupper på tre har drevet veiledning med hverandre slik at hver av deltakerne har fått besøk i sin undervisning tre ganger med påfølgende veiledningssamtaler. Samtlige deltakere har dessuten fătt noe opplæring om slik veiledning og har truffet hverandre et par ganger i løpet av året og utvekslet erfaringer. Som kompensasjon for sin deltakelse i prosjektet har de fătt 40 timers reduksjon i øvrige arbeidsoppgaver. Erfaringene ser ut til å være meget gode, og et nytt kull med 30 deltakere er i gang med et tilsvarende opplegg. (Mer informasjon: http://www. hum.au.dk/cfu/sider/indsatsomraader/supervision. htm)

Lignende forsøk i mindre skala har vært utprøvd også andre steder men mer sporadisk. Erfaringer tilsier at det er viktig at deltakerne får hjelp til å gjøre seg kjent med denne veiledningsformen og til å kvalifisere seg for den typen observasjoner og samtaler som er sentrale i den (Lauvås \& Rump 2001). Det vil også være nyttig om de små veiledningsgruppene kan få tilgang til bistand fra personer med mer profesjonell kompetanse på dette området som kan bidra med innspill ut fra perspektiver som deltakerne ikke selv umiddelbart trekker frem.

I pedagogisk litteratur forekommer begrepet "kritisk venn" som en måte å gripe ideen med slik veiledning (Simons 1987, Tiller 1990). Kritiske venner kjennetegnes nettopp ved kombinasjonen av vennskap (assosiert med støtte, bekreftelse og lojalitet) og kritikk (assosiert med analyse, vurdering, påpeking av utilfredsstillende praksis og krav om kvalitet) (Handal 1999 og 2006). Det er denne kombinasjonen som er viktig for at læring og videreutvikling av deltakernes praksisteori virkelig skal bli realisert, fordi den kombinerer sosial og følelsesmessig trygghet og støtte med intellektuell utfordring med hensyn til å forstå og mestre de oppgavene en står overfor $\mathrm{i}$ undervisningen.

Som veileder i slik veiledning med kolleger er det viktig å lytte og prøve å forstå hvordan din kollega opplever og forstår den situasjonen som du skal veilede om, hva vedkommende ser som utfordringer og problemer og hvordan han/hun tenker om den undervisningen det handler om. Det er kollegaens forståelse - ikke din - som er utgangspunktet for veiledningen. Først i neste runde av samtalen kan det åpnes for drøfting av andre mulige måter å forstå situasjonen på, andre (f. eks. dine) kunnskaper og erfaringer, andre perspektiver enn kollegaens. Dette skillet mellom 'innenparadigmatisk' og 'utenomparadigmatisk' veiledningssamtale er viktig. Først må en "finde ham der, hvor han er og begynde der" (som Kierkegaard (1859) sier) og "forstaae det, han forstaaer". Bare deretter kan en eventuelt "begynde i en anden Forstand «.

Det er krevende å være veileder om en vil være en kritisk venn. Det krever vilje til å utvikle sin kompe- 
tanse for slik veiledning, en viss evne til empati og en porsjon integritet. Men det er lærerikt og givende også for veilederen. Å bli veiledet på denne måten krever også sitt. Den som blir veiledet må våge litt ved å stille seg og sin praksis til disposisjon for veiledning. Skal det dessuten være verd innsatsen, må en også være innstilt på å forandre noe ved sin praksis som en selv erkjenner kan bli bedre og ikke i utgangspunktet være overbevist om at alt er såre godt som det er, og at slik bør det fortsatt være.

Er kollegial veiledning om undervisning en for stor utfordring for lærere i videregående utdannelse? At det er trangt om plass på arbeidsplanen og at det er konkurranse om tid til gode formål er et forhold vi bare må anerkjenne. Men ville vi engasjere oss i slik veiledning om det ble avsatt rom for det? Er undervisning viktig nok til å bli tatt så på alvor som en kollegial veiledning legger opp til? Og er våre arbeidsgivere - universiteter og høgskoler (utenom Århus!) - villige til å satse på en slik veiledning for å bidra til kvaliteten i undervisningen?

\section{Referanser:}

Bartlett, A. \& G. Mercer (2000): Reconceptualising discourses of power in postgraduate pedagogies. Teaching in Higher Education, 5, 2:195-204

Bergenheim, Å. (2001): Inspirationskälla, föredöme, tränare och kollega. Forskarhandledares visioner och verklighet. Skriftserie från förvaltningen, 2001:1, Universitetspedagogiskt centrum, Umeå Universitet

Brinko, K. T. (1993): The practice of giving feedback to improved teaching. What is effective? Journal of Higher Education, 64:5, 574-93

Brown, R. (1994): The 'Big Picture' about Managing Writing. I: Zuber-Skerritt, O \& Y Ryan (Eds.): Quality in Postgraduate Education. London: Kogan Page

Brown, G. \& M. Atkins (1988): Effective teaching in higher education. London: Routledge

Degerblad, J.-W. \& S. Hägglund (2002): Tradition och förnyelse $i$ svensk forskarutbildning. Högskoleverkets rapportserie 2002:26. Stockholm: Högskoleverket

Delamont, S., P. Atkinson \& O. Parry (2004): Supervising the Doctorate. Maidenhead: Open University Press

Dysthe, O. (2002): Professors as mediators of academic text cultures An interview study with advisors and master degree students in three disciplines in a Norwegian university. Written Communication, 19, 4:493-544

Frischer, J. \& K. Larsson (2000): Laissez-faire in research education - an inquiry into a Swedish doctoral program. Higher Educaton Policy, $13,131-155$

Grant, B. M. (2005): The pedagogy of graduate supervision: figuring out the relations between supervisor and student. Auckland: The University of Auckland, Aoteraroa, New Zealand
Handal, G. (1999): Kritiske venner - bruk av interkollegial kritik innen universiteten. Nying nr 9. Linköping: Linköpings tekniska högskola.

Handal, G. (2006): Kritiske venner. I: Strømsø, H., K.H. Lycke \& P. Lauvås (red): Når laering er det viktigste. Undervisning $i$ hoyere utdanning. Oslo: Cappelen Akademisk Forlag.

Handal, G \& P. Lauvås (2002): På egne vilkår. En strategi for vejledning med larere. Århus: Forlaget KLIM

Handal, G. \& P. Lauvås (2006): Forskningsveilederen. Oslo: Cappelen Akademisk

Johnson, S. (1997): Thinking about postgraduate supervision as a teaching/learning process. Paper presentert ved Biennial Conference of the International Study Association on Teacher Thinking, Kiel, oktober

Kierkegaard, S. (1859): Synspunktet for min forfattervirksomhed. Rapport til historien. Paragraf 2. Samlede værker, 13. København: Nordisk Forlag.

Larsson, S. (2004): The joy and despair of writing. Nordisk Pedagogik, 24, 2:97-112

Lauvås, P., K.H. Lycke \& G. Handal (1996): Kollegavejledning $i$ skolen. Århus: Forlaget KLIM

Lauvås, P. \& G. Handal (1997): Vejledning og praktisk fagteori. Århus: Forlaget KLIM.

Lauvås, P. \& G. Handal (2005): Optimal use of feedback in research supervision with master and doctoral students. Nordisk Pedagogik, $25,3: 177-189$

Lauvås, P. \& C. Rump (2001): Vor feelles viden. Kollegavejledning som metode til udvikling af undervisning ved højere lareanstalter. Frederiksberg: Samfundslitteratur

Lave, J. \& E. Wenger (1991): Situated Learning: Legitimate Peripheral Participation. New Jersey: Cambridge University Press

Lindén, J. (1998): Handledning av doktorander. Nora: Bokförlaget Nya Doxa

Ludvigsen, S. R. (1998): Læring av klinisk resonnering i medisinsk utdannings- og arbeidskontekst. Dr.polit.-avhandling, Universitetet i Oslo, Pedagogisk forskningsinstitutt

Nielsen, K. \& S. Kvale (red.) (1999): Mesterlare. Loring som social praksis. København: Hans Reitzels forlag

Rehn,A. (2003): Quick and dirty. I: Strannegaard, L. (red.): Avhandlingen. Om att formas till forskare. Lund: Studentlitteratur

Rugg, G. \& M. Petre (2004): The unwritten rules of PhD research. Maidenhead: Open University Press

Simons, H. (1987): Getting to know schools in a democracy: The politics and process of evaluation. London: Falmer Press

Stenström, E. (2003): Formen är normen. I: Strannegård, L. (red.): Avhandlingen. Om att formas till forskare. Lund: Studentlitteratur.

Stray Jørgensen, P. \& L. Rienecker (2006): Specielt om specialer - hovedsakeligt om hovedopgaver - koncentreret om kandidatafhandlinger. 3. utg. Frederiksberg: Samfundslitteratur

Tiller, T. (1990): Kenguruskolen: Det store spranget. Oslo: Gyldendal

Tofteskov, J. (1996): Projektvejledning. Frederiksberg: Samfundslitteratur

Wichmann-Hansen, G. (2004): Praktik i lageuddannelsen. Et kvalitativt studie om laering og vejledning i klinikken. ( $\mathrm{PhD}$-afhandling). Aarhus Universitet, Det Sundhedsvidenskabelige Fakultet 